\title{
Transnational sustainability certification for the bioeconomy? Patterns and discourse coalitions of resistance and alternatives in biomass exporting regions
}

Thomas Vogelpohl ${ }^{*}$ (D)

\begin{abstract}
The bioeconomy is nowadays widely proclaimed by governments and corporations around the world as a new paradigm for a sustainable economy. Essentially, it broadly denotes the promotion, development and establishment of the use of biogenic resources in diverse kinds of industrial technologies, production processes and products. Yet, in order for the bioeconomy to be sustainable, it has to be assured that these biogenic resources are sourced sustainably. In the last 30 years, transnational sustainability certification (TSC) has established itself as a popular instrument in this context, for example in the case of European biofuels sustainability regulation. In the last decade or so, however, TSC initiatives in several biomass production sectors like palm oil, soy, fruits, aquaculture or fisheries-mostly initiated by non-governmental organizations (NGOs) and corporations from the Global North-are increasingly met with resistance from actors from the resource-producing countries, mostly located in the Global South. Issues brought up in this context concern their lack of legitimacy and respect for national regulatory sovereignty and conflicting priorities in terms of sustainable development. Consequently, governmental and corporate actors from the resourceproducing countries have developed sustainability standards that now at least partly compete with TSC. Against this background, this contribution investigates this apparent dilemma of biomass certification by taking stock of existing TSC initiatives and territorial responses to them in several sectors of the bioeconomy in order to discover general patterns and dynamics of transnational biomass sustainability certification. This analysis is based on a review of existing empirical studies on these issues as well as on conceptual literature on discourse coalitions and transnational hybrid governance for the classification of the different aspects and developments in the individual sectors. Results show that TSC is indeed challenged in all sectors around story lines of sovereignty and sustainability, employed by closely associated state and industry actors in the specific context of the prevalent state-industry relations and the practices and institutions of the respective international political economies. Beyond this general pattern, these alternative systems take on different shapes and complex relations between transnational and territorial sustainability governance emerge that are not always antagonistic, but also exist in parallel or even complementarily and involve various hybrid configurations of public and private actors. Overall, this casts some doubt on the potential of TSC as an instrument to safeguard the sustainability of the bioeconomy and shows one of its potential pitfalls, which is reflected upon in the conclusion.
\end{abstract}

*Correspondence: thomas.vogelpohl@fernuni-hagen.de

Chair for Policy Analysis and Environmental Policy, Institute of Political

Science, Faculty of Humanities and Social Science, FernUniversität

in Hagen, Universitätsstr. 33, 58084 Hagen, Germany

(c) The Author(s) 2021. Open Access This article is licensed under a Creative Commons Attribution 4.0 International License, which permits use, sharing, adaptation, distribution and reproduction in any medium or format, as long as you give appropriate credit to the original author(s) and the source, provide a link to the Creative Commons licence, and indicate if changes were made. The images or other third party material in this article are included in the article's Creative Commons licence, unless indicated otherwise in a credit line to the material. If material is not included in the article's Creative Commons licence and your intended use is not permitted by statutory regulation or exceeds the permitted use, you will need to obtain permission directly from the copyright holder. To view a copy of this licence, visit http://creativecommons.org/licenses/by/4.0/. The Creative Commons Public Domain Dedication waiver (http://creativeco mmons.org/publicdomain/zero/1.0/) applies to the data made available in this article, unless otherwise stated in a credit line to the data. 
Keywords: Bioeconomy, Sustainability certification, Transnational hybrid governance, Territorialized resistance, Discourse coalitions

\section{Background: the bioeconomy and sustainability certification}

The concept of the bioeconomy has recently risen to great popularity with governments and corporations around the world as a new paradigm for a sustainable economy. At its conceptual core, the bioeconomy broadly covers the promotion, development and establishment of the use of biogenic resources in diverse kinds of industrial technologies, production processes and products [see, e.g., 1-3]. Within the last decade, the concept that is rooted in strategic considerations for research and innovation policy of the Organisation for Economic Cooperation and Development (OECD) and the European Union (EU) developed into to a fully fledged political project. It has found its way into the strategies of international innovation policy and has become an essential component of economic development for Europe and beyond in order to meet the global challenges of the twenty-first century such as climate change, securing the supply of raw materials and energy for the economy and society, or food security [see, e.g., 1-3].

Beyond the basic conception mentioned above, however, it is highly contentious what the bioeconomy actually is or should be [see, e.g., 4-7]. In recent years, therefore, the politically dominant take on the concept of the bioeconomy along economic growth and the global commercialization of biotechnological innovations is increasingly contested by broader and alternative concepts and visions of a post-fossil economy [8-10]. Another major critique refers to the amount of biomass resources necessary for substituting fossil resources and the problem of sustainably sourcing all these resources in times of social and ecological land-use issues such as finite resources, agricultural intensification, land grabbing or indirect land-use change [see, e.g., 11, 12].

Thus, policy-makers are looking for instruments and mechanisms to govern the sustainability of the bioeconomy. There is a plethora of governance frameworks and potential policy instruments to choose from in this regard [13, 14, for recent overviews see, e.g., 15-17]. One potential policy instrument among these that is perpetually discussed in this context is sustainability certification of bio-based products, since it "can help to manage biogenic resources and their derived products in a sustainable manner" $[18$, p. 2]. This is especially true for transnational sustainability certification (TSC), since the bioeconomy, at least in its current incarnation, is relying heavily on the transnational trade of biogenic resources.
Peter Vandergeest describes TSC as "non-state agencies operating transnationally (...) with the express purpose of claiming rule-making authority with respect to ecologi$\mathrm{cal}$ and social practices. Specifically, they seek to identify operators who can demonstrate compliance with standards as verified by 'third-party' certification" [19, p. 271]. ${ }^{1}$

The rise of TSC systems is part of a general increase in private, transnational environmental governance initiatives, which, due to their decentralization and flexibility, have been perceived as at least a potential response to market and state failure at various levels [see, e.g., 24-26]. However, the rise of such private governance rules was not only accompanied by euphoria, but also by skepticism. In addition to doubts about their effectiveness and their sometimes regulation-preventing character, this skepticism primarily concerns the question of legitimacy. Unlike government institutions, which do so at least indirectly, private governance systems do not represent the people they affect and cannot necessarily be held accountable by them. In the absence of a supranational authority, and especially when they have a lot of market power or when they are incorporated into state regulation, legitimacy must therefore be actively achieved through new sources by these systems of transnational private governance [26-30].

In the case of EU biofuel sustainability regulation, however, private certification schemes for biofuels are included into state regulation [31]. What we have here is therefore not only a private governance system, but a hybrid governance ${ }^{2}$ arrangement "beyond the public-private divide" [34], which is supposed maintain the advantages of private governance while at the same time remedying their disadvantages, such as their lack of

\footnotetext{
1 The term has been used similarly before by other authors as a special form transnational, non-state governance [see, e.g., 20-23].

2 I follow Ponte and Daugbjerg [20, p. 99] here in their definition of hybrid governance as "more than a varying combination of public and private components of governance-it denotes their mutual dependence and deep interrelation. Thus, THG [transnational hybrid governance] is characterised by polyarchic and overlapping governance arenas, where interactions between a variety of mutually dependent private and public actors give rise to hybrid regulatory features, and where collective orders and individuals engage in cross-border rulemaking, implementation, and enforcement activities." In that, hybrid governance is similar to the concept of co-regulation [see, e.g., 32]. However, as Steurer [33, p. 401] notes, it also differs from it in that "co-regulation represents basic (yet domain-spanning) types of regulation with unique rather than hybrid characteristics". Therefore, I follow him here in his proposition "to restrict hybrid regulation to those practices that truly combine two (or more) of the seven basic types of regulation to something new" [ibid.].
} 
legitimacy, through the link with state regulation. Therefore, sustainability certification within the framework of EU biofuel policy also plays a special role for the bioeconomy, since many actors see it as a kind of test balloon for politically prescribed sustainability certification, from which lessons could be drawn for a possible extension of it to the bioeconomy as a whole [see, e.g., 16, 35, 36]. ${ }^{3}$ However, recent evaluations on the capability and effectiveness of this public-private governance arrangement for sustainability certification come to rather sobering results in terms of its performance. Thus, it was, inter alia, criticized for:

- not including some important sustainability aspects related to biofuel production, such as indirect landuse change or social aspects in general [see, e.g., 37, 38],

- a lack of supervision of the recognized voluntary schemes [see, e.g., 37-39],

- a lack of transparency in the certification and auditing process [see, e.g., 38, 40],

- the proliferation and fragmentation of recognized schemes, which leads to a kind of 'race to the bottom' in complying with sustainability criteria [see, e.g., 38, 40], or

- a lack of democratic legitimacy as regards the participation of affected stakeholders and the accountability of involved industrial actors [see, e.g., 37-39].

Therewith, these evaluations of the EU's biofuels governance arrangement for sustainability certification join a large and growing number of critical accounts on biomass-related TSC systems ranging from forestry via agriculture to marine-based production, mainly based on poor ecological effectiveness, social exclusion especially of smallholders and local communities, and a general lack of democratic legitimacy and accountability [see, e.g., 41-50]. In many of these cases, observers and critics see the danger of corporate prestige cultivation via sustainability certification, which would therefore rather be a fig leaf or greenwash of environmental and social exploitation than actually bringing forward sustainability [see, e.g., 35, 36].

Based on these general doubts regarding the promise of effectiveness and legitimacy of public-private governance, in the last decade, there is a recent development of resistance against transnational biomass sustainability certification schemes-mainly, but not only in the Global South-that in some cases has led to the development of

\footnotetext{
${ }^{3}$ Actually, there are already many private and public biomass sustainability certification schemes in place on which one could rely on in this context [see, e.g., 18 for an overview with a focus on Europe].
}

alternative certification schemes and that further puts into question the potential of this instrument in helping to bring about a sustainable bioeconomy. From a political ecology perspective, this phenomenon can be described as the "territorialization of transnational sustainability governance" [51]. Rooted in critical political economy, territoriality is defined by Sack as the "attempt by an individual or group to affect, influence, or control people, phenomena, and relationships by delimiting and asserting control over a geographic area" [52, p. 19]. Territorialization thus describes "specific territorial projects in which various actors deploy territorial strategies (territoriality) to produce bounded and controlled spaces (territory) to (...) to govern people and resources located within and around the territory" [53]. From this perspective, following Foley and Havice [54, p. 31], the institutionalization of alternatives to TSC within and around a certain territory, represents.

"the territorial re-making of transnational sustainability governance (...) through integrated networks among territorially embedded (...) production interests, state regulatory and marketing institutions, and international market dynamics and governance norms. It serves to shore up the territorial, often national, industry identities and features of place-specific production and state-based regulatory regimes, and pushes these features beyond the spatial boundaries of the state by promoting them for recognition in global markets."

As this quotes shows, and as Foley notes, "territorialization and transnationalization are not mutually exclusive" [51, p. 920], since territorial sustainability certification still relies on transnational institutions and access to global markets, e.g., to sell certified products beyond the own territory.

The present article provides a selective overview of these developments of territorialized resistance against and alternatives to biomass TSC. Thereby, it seeks to contribute to the debate on how to make the bioeconomy sustainable by showing the problems a simple extension of the mode of "transnational hybrid governance", as it is deployed in the EU RED [see, e.g., chapter 5 in 55], to all kinds of biomass would entail.

The article proceeds as follows: in the following chapter, I will briefly present an analytical framework to examine resistance against transnational sustainability certification and the development of territorial alternatives to it, which will then be applied to selected cases from the field transnational biomass sustainability certification. The article is wrapped up with a conclusion on the perspectives for sustainability certification for the bioeconomy. 
Table 1 Selected cases of TSC systems and territorial alternatives to them

\begin{tabular}{|c|c|c|c|c|c|c|c|c|}
\hline \multirow[t]{2}{*}{ Sector } & \multicolumn{4}{|l|}{ TSC systems } & \multicolumn{4}{|c|}{ Territorial alternative systems } \\
\hline & Name & Founded & Seat & Structure & Name & Founded & Seat & Structure \\
\hline \multirow[t]{2}{*}{ Palm oil } & \multirow[t]{2}{*}{ RSPO } & \multirow[t]{2}{*}{2004} & \multirow[t]{2}{*}{$\mathrm{CH}$} & \multirow[t]{2}{*}{ MSI } & ISPO & 2009 & Indonesia & State \\
\hline & & & & & MSPO & 2013 & Malaysia & State \\
\hline Soy & RTRS & 2004 & $\mathrm{CH}$ & MSI & Soja Plus & 2010 & Brazil & Industry \\
\hline \multirow[t]{2}{*}{ Fruit } & GLOBALG.A.P. & 1997 & DE & Industry & \multirow[t]{2}{*}{ SIZA } & \multirow[t]{2}{*}{2008} & \multirow{2}{*}{$\begin{array}{l}\text { South } \\
\text { Africa }\end{array}$} & \multirow[t]{2}{*}{ Industry } \\
\hline & ETI & 1998 & GB & MSI & & & & \\
\hline \multirow[t]{3}{*}{ Fisheries } & \multirow[t]{3}{*}{ MSC } & \multirow[t]{3}{*}{1997} & \multirow[t]{3}{*}{ GB } & \multirow[t]{3}{*}{ MSI } & IRF & 2009 & Iceland & Industry \\
\hline & & & & & MEL & 2007 & Japan & $\begin{array}{l}\text { State/ } \\
\text { Industry }\end{array}$ \\
\hline & & & & & RFM & 2011 & Alaska & Industry \\
\hline \multirow[t]{2}{*}{ Aquaculture } & ACC & 1997 & US & Industry & GAP & $2002 / 2009$ & Thailand & State \\
\hline & ASC & 2010 & $\mathrm{NL} / \mathrm{GB}$ & MSI & VietGAP & 2011 & Vietnam & $\begin{array}{l}\text { State/ } \\
\text { Industry }\end{array}$ \\
\hline
\end{tabular}

\section{Main text: patterns and discourse coalitions of resistance against and alternatives to TSC Overview of cases and conceptual approach}

This review is based on a number of cases of resistance against and alternatives to private TSC systems from the sectors of palm oil, soy, fruit, fish, and aquaculture. The selection of these cases was made on the grounds of case fit and the availability of data and secondary literature on the components of the discourse coalitions approach via desk research. It should be noted therefore that this is not by any means an exhaustive selection of such cases, neither in terms of private TSC systems nor regarding alternative national systems, which is why I don't claim to present a comprehensive picture of the phenomenon here. Furthermore, this study is not able to systematically evaluate the actual sustainability performance of the systems, even though I refer to respective evaluations occasionally. Rather, the selected cases are supposed to illustrate the growing phenomenon of territorialized alternatives to private TSC systems based on the criteria mentioned above.

Table 1 shows an overview of the cases and their main characteristics. As can be seen, the cases share a couple of interesting features. First, almost all of the considered TSC systems were founded roughly around the turn of the millennium, between 1997 and 2004, while the considered alternative systems were started roughly a decade later, between 2007 and 2014. Secondly, and hardly surprisingly, the considered TSC systems are all initiated and led by private actors, be it industry-led systems or multi-stakeholder initiatives (MSIs), in which non-governmental organizations (NGOs) often play a leading role. The alternative schemes, in contrast, are exclusively led by domestic state or industry actors and do not or only rarely involve civil society actors. Thirdly, the table shows that the private TSC systems are all based in the Global North, mainly in Europe, but also in the United States (US). The alternative systems, on the other hand, are all based in the biomass exporting countries, which, with the exception of the fisheries sector, are almost exclusively in the Global South.

More details on the individual cases of resistance against and territorial alternatives to private TSC systems will be provided below as these cases are analyzed along the components of the discourse coalitions approach. This approach is based on Maarten Hajer's argumentative discourse analysis. Discourse here "is defined as an interplay of ideas, concepts and categories through which phenomena are assigned a meaning that is produced and reproduced by identifiable practices" [56, p. 44]. Thus, it means more than just discussions, language or text. Rather, Hajer is concerned with making the discursive production, reproduction and modification of social power and power relations comprehensible and analyzable.

In order to do so, Hajer develops the concept of discourse coalitions, which are defined as "the ensemble of particular story-lines, the actors who employ them, and the practices through which the discourse involved exerts its power" [57, p. 60]. Thus, at the center of discourse coalitions are the story lines, which Hajer describes as "condensed statement[s] summarizing complex narratives, used by people as 'short hand' in discussions" [58, p. 69] and thereby providing "the discursive cement that keeps a discourse-coalition together" [56, p. 65]. Discourse coalitions are organized around these story lines, which are not so much characterized by a particular set of actors employing them, but rather by the specific institutional contexts and practices, within which they are produced. Practices are here generally defined as "embedded 
routines and mutually understood rules and norms that provide coherence to social life" [58, p. 70].

If such a discourse coalition begins to influence the way in which a "a given social unit (a policy domain, a firm, a society) conceptualizes the world", this is referred to as the phase of discourse structuration [58, p. 70]. If a discourse condenses into certain institutional regulations we speak of the status of discourse institutionalization and if "both criteria are fulfilled we argue that a particular discourse is dominant" [58, p. 70].

The discourse coalition approach can shed light on "how different actors and organizational practices help to reproduce or fight a given bias without necessarily orchestrating or coordinating or without necessarily sharing deep values" [58, p. 71]. Following, I will illustrate how this played out regarding the phenomenon of resistance against and alternatives to TSC and how it is structured along the components of the discourse coalitions approach, i.e., the main story lines, the actors that employ them, and the practices, in the context of which they are employed and gain meaning.

\section{Story lines of sovereignty and sustainability}

When applying the discourse coalition framework to these cases of resistance against TSC, it is possible to distill common story lines of a counter-TSC discourse coalition. A central story line in this context is the one of a lack of legitimacy of TSC initiatives, which has been criticized in general (see above), but also in particular with respect to the cases briefly introduced above. For example, in the case of palm oil, the legitimacy of the Roundtable for Sustainable Palm Oil (RSPO) has been questioned, as particularly smallholders and indigenous peoples have not been sufficiently represented and involved. In general, there is a lack of balance regarding the membership of and influence on the RSPO between upstream actors (producers, processors) and downstream actors (manufacturers, retailers) of the palm oil value chain [see, e.g., $41,44,46,49,59,60]$. On these grounds and especially among these upstream actor groups, the story line of a lack of legitimacy of the RSPO emerged, according to which the "RSPO is skewed in favour of the manufacturers and retailers, whilst the bulk of the certification costs sit with the growers" [61, p. 178].

This lack of legitimacy of the RSPO is closely related to certain story lines of sovereignty over palm oil production and its meaning. Schouten and Hospes analyzed this aspect more closely in a recent study and they found that the Indonesian government initially "implicitly practiced a notion of interdependence sovereignty, in which state and non-state actors share control over cross-border flows of goods" [62, p. 5]. In the course of time, however, this relationship became more competitive than cooperative as "notions of interdependence sovereignty have faded, and have been replaced by notions of domestic and Westphalian sovereignty" [62, p. 9]. This can be read as a counter movement against the previous redefinition of Westphalian territorial jurisdiction and state sovereignty by NGO-led TSC initiatives that "arguably constitute forms of supragovernmental legalization or even legal extraterritoriality" [51, p. 920, see also 63, 64].

In terms of the other cases, we find very similar story lines of sovereignty around which the counter-TSC discourse structures. Just like the RSPO, the Roundtable for Responsible Soy (RTRS) "has struggled with a variety of legitimacy challenges", such as a low and unbalanced membership, a lack of civil society involvement or the perceived unfair distribution of costs and benefits between producing and importing countries [61, p. 179]. Again, this is a question of sovereignty as the alternative, producer-led initiative Soja Plus, just like ISPO, is a means to "proclaim the sovereignty of the state as the highest political authority to decide on what is acceptable" [65, p. 434]. Similarly, the Sustainability Initiative of South Africa (SIZA) was founded by domestic fruit producers because it was "developed, owned and operated in South Africa and not imposed from the outside" in order "to promote itself as a local initiative, the first of its kind in the world" [66, p. 304].

As regards the counter-TSC cases in the fisheries sector, Foley and Havice [54] consider the control over national authority and production as well as over national reputation and territorial representation as central motivations for domestic producers and authorities for resisting against external influence from privates TSC schemes, mostly from the Marine Stewardship Council (MSC). In terms of Alaska, particularly, Foley generally states that "the influence of ideational and cultural politics of territorial independence and nationalism" have played a pivotal role in resisting the MSC and developing a territorial alternative to it [51, p. 924, see also 67]. Icelanders, according to Foley, similarly "tend to invoke a strong cultural identity of independence (...) [that] often manifests as resistance to external influence, such as ongoing resistance to joining the European Union and initial resistance to the MSC" [51, p. 924].

The same is true for the aquaculture cases in Thailand and Vietnam. As Vandergeest and Unno state, Thai state and industry actors were "unanimous in being strongly critical of what they saw as foreign certification" and that "they thought that it was properly the role of the Thai government to deal with environmental and social issues in Thailand, not foreign institutions. They articulated their arguments in terms of nationalism and sovereignty " [64, p. 364]. TSC initiatives such as the Aquaculture Certification Council (ACC) or the Aquaculture Stewardship 
Council (ASC), in comparison, were seen "as a way for rich countries to control and take advantage of developing countries" [64, p. 364]. There are reports of similarly critical viewpoints of TSC as diminishing the government's sovereign control over the aquaculture industry by state and industry actors from Bangladesh or Vietnam, for example $[68,69]$.

These specific interpretations of sovereignty are often closely related to a specific interpretation of sustainability. Thus, the sustainability story line is as central to the counter-TSC discourse coalition as it is to the original TSC discourse. For the case of palm oil, for example, Hinkes [70] notes that the actors constituting the palm oil counter-TSC discourse coalition employ story lines of sustainability that differ markedly from the RSPO interpretation of sustainability. Thus, they construe palm oil as inherently sustainable due to its efficiency and productivity [see also 50, 71]. Furthermore, they widen the scope of sustainability to the livelihoods of smallholders, which would be threatened by RSPO-like sustainability certification. Similarly, Higgins and Richards find that the alternative certification systems Indonesia Sustainable Palm Oil (ISPO) and Malaysian Sustainable Palm Oil (MSPO) "enable a reframing of sustainability that bypasses the perceived challenges and limitations associated with RSPO" [72, p. 132].

Regarding Soja Plus, story lines of sustainability are not at the heart of the program. Nonetheless, the statement on their website, according to which "sustainability requires efficient production, with high levels of quality and productivity, that does not compromise future generations" [73], points to a specific, industry- and production-friendly interpretation of sustainability, which is, however, not a Brazil- or soy-specific one, but rather in line with a "consensual 'sustainable development as integration' discourse" [74, p. 187].

In fisheries, responding strategically to the MSC in particular and to the transnational sustainable seafood movement in general were among the main motivations behind developing territorial alternatives. This is reflected in the challenging of TSC story lines of sustainability by domestic actors, who are eager to communicate that their national practices of fishing and managing the fishery industry "had a well-established historic reputation of sustainability" (Alaska) or "are already sustainable because of the regulatory terms of and improvements made" [US, 54, p. 28]. The alternative schemes in this context enabled "fishermen to tell their own narrative of fisheries success, rather than to have an outsider (Western) narrative of fisheries crisis being told for them through the need for an MSC eco-label" [54]. Regarding the Iceland Responsible Fisheries (IRF) certification program in Iceland, Foley similarly notes that the ability to "communicate and brand Icelandic fishery attributes of responsibility and sustainability" was one of the major factors contributing to the development of a collective national response to the MSC in form of the IRF [51, p. 927].

Furthermore, these story lines of sustainability and sovereignty are often accompanied by anti-NGO-story lines criticizing the influence of transnational NGOs on the domestic economies. In the case of palm oil, for example, the founders of ISPO criticized RSPO for listening "to the voice of foreign NGOs more than government and business" [75]. Part of the motivation behind founding MSPO, similarly, was the "the increasing influence of Western environmental NGOs on the multi-stakeholder initiative and the resultant pressures on large-scale and small-scale producers" [76].

Similar criticism of and frustration with international environmental NGOs can be found in the other cases, too. In the case of fisheries, for example, Foley considers "general hostility toward environmental NGOs because of prior attacks on the national whaling industry" as one of the main factors driving local producer resistance against the MSC in Iceland [51, p. 924]. In case of the Alaskan MRF program, "actors were similarly motivated by concerns over intrusion by NGOs into the fishery management process and industry's perception that standards can be changed at the discretion of NGOs and (...) that NGOs have control over what is deemed sustainable" [54, p. 28]. In case of SIZA, Schouten and Bitzer cite one interviewee from a domestic producer association, according to whose "personal opinion (...), this Human Rights Watch and these types of NGOs, they try and find problems" [61, p. 180].

\section{Territorial(izing) state and industry actors}

For the question whether the discontent with a TSC system and respective story lines centering on specific interpretations of sovereignty and sustainability are translated into resistance against it and eventually into alternatives to it, it is important what actors employ these story lines. As already pointed out above, domestic state and industries actors play pivotal roles in this context, especially when it comes to the organization of alternative certification systems.

In the case of palm oil in Indonesia and Malaysia, it was mainly the national governments that became skeptical of the $\mathrm{RSPO}^{4}$ and eventually started the alternative certification systems ISPO and MSPO. Both these systems are state-initiated and coordinated within the framework of

\footnotetext{
${ }^{4}$ Wijaya and Glasbergen [77] have taken a closer look at the development of the Indonesian government's attitude towards transnational sustainability certification in the form of the RSPO and have traced how this has changed from
} 
the Council of Palm Oil Producing Countries (CPOPC), a kind of palm oil cartel [78]. ISPO was started and spearheaded by the Indonesian government, specifically by the Indonesian Palm Oil Commission (IPOC), which is a government agency responsible for the promotion and development of the palm oil industry within the Ministry of Agriculture [65]. MSPO, in slight contrast, was started via a cooperation of the Malaysian government with the Malaysian palm oil industry. Thus, while being state-led, the two big palm oil producer associations, the Indonesian Palm Oil Association (GAPKI) and the Malaysian Palm Oil Association (MPOA), do play a considerable role here as they support ISPO and MSPO, respectively. ${ }^{5}$ This speaks to the close relation between the state and the palm-oil industry in Malaysia and Indonesia, which Oliver Pye characterized as the "palm oil industrial complex" [80]. "Palm oil is regarded a strategic economic sector in both Malaysia and Indonesia", as Nesadurai notes [81, p. 208], which is why state actors were central to starting both ISPO and MSPO as alternatives to the RSPO, albeit to different degrees. ${ }^{6}$

As regards the development of Soja Plus as an alternative to the RTRS in Brazilian soy sector, the role of the state was much less prominent, as it was started through a cooperation of soy and agriculture industry association. Though the state therefore played a minor role in this case, however, Schouten and Bitzer note that "Soja Plus, while being a private initiative, emphasizes its close linkages to governmental regulation" [61, p. 179]. The South African fruit industry launched its own ethical program SIZA in 2008 as a reaction to the influence of the Global Partnership for Good Agricultural Practice (GLOBALG.A.P.) and the Ethical Trading Initiative (ETI) on its market. ${ }^{7}$ Similar to Soja Plus, SIZA is run almost solely by the South African fruit industry, albeit with support of the state and also in cooperation with retailers and civil society organizations [61].

\footnotetext{
Footnote 4 (continued)

indifferent to cooperative to antagonistic, which ultimately led to the initiation of ISPO.

5 Therefore, MSPO and ISPOs do indeed represent competition to the RSPO. Indicative of this is, for example, that GAPKI supported the development of ISPO from the outset and, in parallel, withdrew from the RSPO as early as 2011 [79, p. 402].

${ }^{6}$ Since both ISPO and MSPO are not recognized under the EU-RED system, they do not present an alternative to the EU RED-recognized RSPO in terms of certifying palm oil for biodiesel use in the EU under the RED. However, palm oil is not only exported to the EU and not only for energy purposes. For example, India and especially China as well as the food or consumer goods industries in general are important potential outlets for certified palm oil, where MSPO or ISPO can compete with RSPO [see, e.g., 82, 83; also see next subchapter].

7 See Thompson and Lockie [84] for a similar case of discontent with GLOBALG.A.P. standards and respective food retailer power in Tasmania/ Australia that, however, did not lead to the foundation of an alternative standard.
}

Regarding the initiatives in the fisheries sector in opposition to the MSC, governments have played an important role in all of them, but mostly not the leading one. However, in all cases investigated by Foley and Havice, (regional or national) governments promoted and supported the mainly industry-led initiatives by providing supportive legal frameworks or research support and technical advice or even by running the development and management of the initiative, which led them to the conclusion that "the state in each case stands to actively expand its own footprint and presence domestically and in global seafood markets" [54], p. 30]. In his in-depth study on the alternative to the MSC in Iceland, the IRF, Foley furthermore points out the joint efforts of Iceland's government and fishing industry "to mobilize a collective state-producer response" to the MSC and "to institutionalize a state-producer initiative" [51, p. 927].

In the case of aquaculture, TSC is led by initiatives such as the ASC (modeled on the MSC) or the industry-sponsored ACC of the Global Aquaculture Alliance (GAA). Even though these aquaculture TSC initiatives so far only cover very little of global aquaculture production [85], they face competition from territorial certification schemes in some of the main aquaculture-seafood producing countries such as Thailand or Vietnam $[64,86]$. In Thailand, this is spearheaded by the state, as the Department of Fisheries initiated the Good Aquaculture Practice (GAP) system as an answer (and an equivalent) to the emerging TSC systems such as ACC already in 2002. In 2009, the scope of GAP was broadened to include environmental and social criteria and to adhere to aquaculture-certification guidelines of the Food and Agriculture Organization of the United Nations (FAO) and guides of the International Organization for Standardization (ISO). In a similar way, the Vietnamese government and industry have jointly initiated a national aquaculture certification scheme, the Vietnamese Good Aquaculture Practices [VietGAP, 86].

Even though there are differences between the cases described here, there are also quite striking similarities, especially between what Pye calls the "palm-oil industrial complex" in Southeast Asia [80] and what Foley calls "state-society complexes" in his study on fisheries in Iceland [51]. In both-and many other-cases, alternatives to TSC are initiated and developed in close cooperation of the respective domestic industries with the respective ministries, governmental agencies and state officials, while NGOs are largely neglected or even actively excluded [see, e.g., 54, p. 29], which is in line with the narratives of sovereignty and sustainability referred to above. 


\section{Practices of (inter)national political economy}

The question whether the story lines and the actors employing them are able to arrange alternatives to the established TSC systems-whether the discourse moves from structuration to institutionalization, so to speaklargely depends on the practices and structures of the (inter)national political economy they are embedded in. Regarding the national political economy, the structure of the domestic market and regulatory system for the respective product plays an important role. While export always remains relevant, it makes a difference to what degree domestic demand can accommodate the supply of the products. If it is able to accommodate a large part of the supply-which also depends on domestic regulations, for example obligations to utilize certain alternative systems-domestic producers (and thus territorialized alternative certification systems) are less dependent on transnational markets. If it is not, the structure of the international political economy and the availability of different outlets for the respective product plays a more important role.

In the case of Soja Plus, for example, conditions for starting an alternative to the RTRS were favorable asdespite "clear signs" from Europe-demand for sustainably certified soy on the transnational market, for example from the US, remained low [61, p. 179]. Thus, the was no pressure to establish a particularly ambitious and potentially burdensome certification system, because there are a number of international outlets for non- or otherwisecertified soy, especially China, as Soja Plus is cooperating with the Chinese Soybean Industry Association [CSIA, 87], but also Europe [88]. Soja Plus, as a consequence, didn't need to focus too much on its credibility in terms sustainability at the international soy market, even though it modeled its scheme quite closely on the RTRS approach [65]. ${ }^{8}$ Schouten and Bitzer in this context conclude that alternative standards from the Global South in general "restrict their focus, at least initially, to internal audiences without any ambition for transnational application. (...) International recognition by external audiences is still important, but seems to be subordinated to acceptance by internal audiences" [61, p. 181].

Even though the national political economy alternative certification systems are embedded in always plays an important role, this conclusion can, however, only partly be extended to the other cases. In the case of SIZA, for example, the international market plays a much bigger role for the South African fruit industry, which is traditionally very export-oriented. As a result, SIZA

\footnotetext{
${ }^{8}$ Initially started out as a certification scheme, however, this certification never came to fruition and Soja Plus diminished to a much less ambitious program, mainly focusing on capacity development for soy farmers.
}

is designed less as an alternative to TSC systems than most of the other cases regarded here. Given the dominance and power of retailers from the Global North, SIZA recognized "the need for international credibility and has engaged with overseas as well as South African retailers to satisfy their requirements and avoid competing expectations" [61, p. 180]. Therefore, SIZA is aligned with the Global Social Compliance Programme (GSCP), which is supported by local and international retailers such as Tesco, Walmart, or Carrefour [89], directly with other standards such as GLOBALG.A.P. [90], or with civil society organizations such as the World Wildlife Fund [WWF, 91]. Thus, SIZA is well integrated into the transnational fruit market and as such, according to Schouten and Bitzer, bears witness "to the growing role of South African actors in actively defining the content of ethical trade programs for the export industry" [61, p. 181].

In the case of palm oil, similarly, domestic demand is not big enough to accommodate large parts of the domestic palm oil production to make Indonesian or Malaysian palm oil production independent from transnational markets [about three quarters of Indonesian and Malaysian palm oil production are exported, [81]. International demand for palm oil, however, is very large and, as is the case with RTRS, the uptake of RSPO-certified remains limited. As a result, the transnational political economy of palm oil is able to accommodate ISPO- or MSPO-certified palm oil. Especially China and India play an important role in this context $[82,83]$. Thus, again very similar to the RTRS, South-South trade relations with India and especially China undermine the RSPO, as producers "faced little risk from continuing with unsustainable operations if they could sell to domestic markets and to the fast-growing new palm oil markets such as in China and India with little interest at that time in procuring certified palm oil" [81, pp. 211-212]. In addition, the Indonesian government hopes to use ISPO to open up new markets for certified palm oil beyond the European one [77]. Furthermore, national regulations guarantee the domestic uptake both of ISPO- and of MSPO-certified palm oil in Indonesia and Malaysia-even if it is not enough to accommodate all domestic palm oil production. Thus, ISPO is not a voluntary certification system, but rather the consolidation of existing palm oil-related regulations in Indonesia under a common regulatory umbrella. All palm oil producers in Indonesia are therefore obliged to comply with the ISPO standard and to be certified accordingly, which is why the amount of ISPOcertified palm oil rose considerably recently [92]. The MSPO, on the other hand, initially was not mandatory for Malaysian palm oil producers and more like a voluntary certification system. Since 2019, however, MSPO 
certification is also binding for all palm oil production in Malaysia [93].

Regarding the fisheries sector, the counter-MSC initiatives also heavily rely on being able to export their certified fish, since they are "evolving within transnational commodity networks that are demanding sustainability certification and driving industry and states' interest in developing initiatives that comply with mounting pressures to demonstrate sustainability" [54, p. 31]. Therefore-and since they were clearly set up as alternatives to the dominating MSC [94] - , they had to make sure to be considered as equally credible and legitimate suppliers of sustainably sourced fish on the transnational market. Besides invoking the story line of inherent sustainability of their territorial fisheries sector (see above), Foley and Havice found that "almost all cases seek compliance with, and emphasize linkages to, transnational organizations and related norms" [54, p. 30]. Therefore, they conclude that these territorial counter-MSC certification initiatives are "also transnational in that they appeal to, and rely on, international authority, particularly the FAO and ISO, to communicate transnationally legible credibility" [54, p. 31]. As regards the Icelandic IRF program, Foley specifically emphasizes the territorial interactions with global governance and states that the IRF's establishment was heavily contingent on the program's "ability to create new institutions that are embedded locally and internationally" [51, pp. 929-930]. Fittingly, he therefore ultimately characterizes it "as a new institution of territorialized transnational sustainability governance, a hybrid form of transnational sustainability governance deeply embedded in territorial social relations yet also embedded in transnational governance and market institutions and norms" [51, pp. 930-931].

The case of the Thai GAP, shows similarities to the counter-MSC cases in the fisheries sector in that it is heavily export-dependent and relies on international norms such as the FAO Guidelines for Responsible Fisheries and Aquaculture or the ISO standard for bodies operating under product certification systems (ISO 65) in order to gain transnational credibility for GAP-certified seafood. GAP certification is quasi-obligatory for Thai seafood exporters since it is state-run and "exportoriented processors no longer accepted shrimp without a GAP certificate" [see also 21, 64, p. 363]. In contrast to the counter-MSC cases in the fisheries sector, however, GAP has not been established in opposition to or to compete with, but rather coexist or even cooperate with private TSC systems such as the ASC or the ACC. Thus, GAP "was portrayed by the Department of Fisheries as Thailand's answer to transnational eco-certification, with the argument it should be accepted by the ACC (...) and the (...) ASC as an equivalent standard" [64, p. 363].
Similarly, the Vietnamese VietGAP system is not only an alternative to private TSC systems but also "acting as an entry standard into international certification schemes like GLOBALG.A.P., ASC, and ACC", because compliance with VietGAP guidelines reduces the certification fees for these TSC systems [86, p. 199].

\section{Conclusion: sustainability certification for the bioeconomy-squaring the circle?}

Summing up, we can speak of a counter-TSC discourse that has structured and institutionalized around context-specific story lines of sovereignty and sustainability, employed by often closely associated national state and industry actors. This discourse coalition allows for the place-specific institutionalization of this discourse in the form of territorialized resistance against private TSC systems and the establishment of alternatives to them. Beyond this general pattern, this means that these alternative systems take on different shapes, mainly contingent on the domestic state-industry re(gu)lations and the practices and institutions of the respective (inter)national political economies they are embedded in (see Fig. 1).

While all alternative systems are initiated by national state and/or industry actors (with no or only a very subordinate role for NGOs), they are very selectively and specifically integrated into or isolated from the transnational markets, mainly depending on the available (domestic or international) outlets for the respective product beyond the TSC-dominated market share. This also determines the relationship of these alternative systems with the established TSC systems. This relationship can be one of competition, as in the case of ISPO and MSPO as alternatives to RSPO for certified palm oil (at least in certain palm oil market sectors, i.e., those not governed under the EU-RED, and regions, such as India or China) or in the case of the IRF as an alternative to the MSC. It can also be one of co-existence, as in the case of Soja Plus and the RTRS, or one of co-operation, as in the cases of SIZA and GLOBALG.A.P. in the fruit sector or GAP or VietGAP and ASC or ACC in the aquaculture sector. Thus, whether territorialized certification schemes actually do provide alternatives to existing TSC systems largely hinges on the specific (trans)national market conditions and by whom and what the certification is specifically sought for, which might present a promising avenue for future research endeavors.

This shows that the "rejection of transnational eco-certification is not a rejection of internationalization" per se [64, p. 365]. Rather, the conclusion of Foley on the Icelandic IRF can be generalized beyond this specific case in that all the cases regarded here are "new institution[s] of territorialized transnational sustainability governance, (...) hybrid form[s] of transnational sustainability 


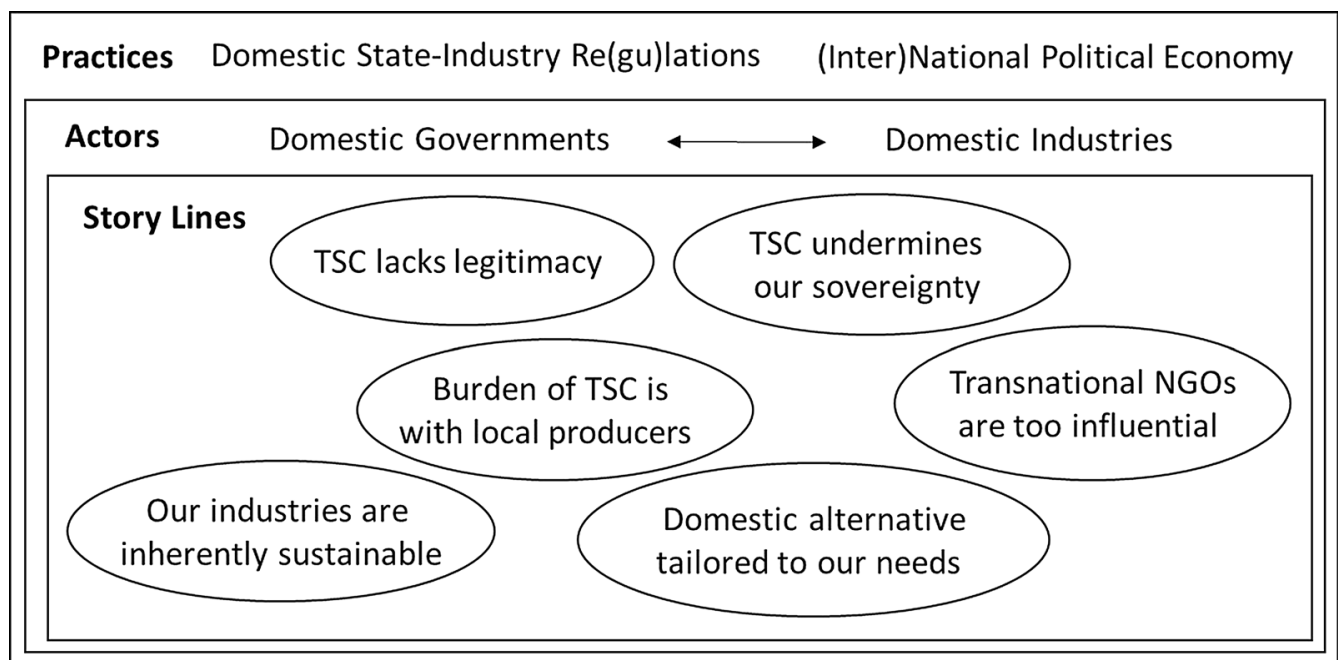

Fig. 1 Basic structure of the counter-TSC discourse coalition

governance deeply embedded in territorial social relations yet also embedded in transnational governance and market institutions and norms" [51, pp. 930-931].

What it also shows is that private TSC as an instrument of transnational environmental governance is under heavy pressure from two sides. On the one hand, actors from the Global North, mainly NGOs, accuse TSC as being "little more than a green fig leaf" for environmental destruction and exploitation of natural resources in the Global South [36, 95, 96, p. 13]. On the other hand, as shown in this paper, actors from the Global South, mainly governments and corporate actors, increasingly view TSC as unwelcome interference in domestic affairs, challenge the normative interpretative sovereignty of importing countries or regions over what 'sustainability' is, as well as the extraterritorial sustainability claims associated with it, and develop alternatives.

Where does this leave us in terms of an outlook for sustainability certification for the bioeconomy? It is hardly debatable that the sustainability of biomass sourcing for the bioeconomy has to be safeguarded in one way or the other. In view of this review, however, one can only come to a somewhat pessimistic conclusion when it comes to the question as to whether sustainability certification can be the solution in this regard. On the one hand, as shown here, private TSC did not really live up to its promise of effectiveness and legitimacy, as both its ecological effectiveness and its social repercussions are questionable. Territorialized eco-certification, on the other hand, even if it is available as an alternative under certain conditions, is not necessarily the better alternative to TSC in terms of legitimacy and sustainability. Irrespective of the credibility and integrity of the resistance against private TSC systems and of the alternative certification systems, it is at least equally questionable as to whether they actually perform better in terms of environmental protection and social inclusiveness. ${ }^{9}$ Apart from that, they are often based on nationalist ideologies and strategies, just as TSC often replicates neo-colonial and imperialist patterns and attitudes [see, e.g., 54, 64].

Beyond this somewhat sobering conclusion, the only remaining insight probably is that the sustainability of biomass production can hardly be guaranteed for the bioeconomy at the global level as long as it is under the premise of economic growth and international competition-at least not by the instrument of sustainability certification. Rather, it is hardly imaginable under this premise how sustainability certification of the entire bioeconomy could combine or balance both ambitious and effective sustainability standards on the one hand and democratic legitimacy and social acceptance on the other. Thus, the actors involved and affected would have to acknowledge that further sustainability certification would ultimately have to prevent the expansion of the cultivation area for the respective biogenic raw material-which, however, in view of the continuing growth paradigm and the associated demand for the respective raw materials, would be tantamount to squaring the circle.

\footnotetext{
${ }^{9}$ With regard to the actual level of ambition of the three rivalling systems in the palm oil sector in terms of sustainability and legitimacy, studies have concluded that RSPO, MSPO and ISPO are relatively similar, but that the RSPO tends to perform better, despite considerable potential for improvement [see, e.g., $65,78,97]$. In a similar vein, Hidayat et al. [98] attribute potential to ISPO, which however cannot be exploited due to a lack of governance capacities on the part of the Indonesian state.
} 


\begin{abstract}
Abbreviations
ACC: Aquaculture Certification Council; ASC: Aquaculture Stewardship Council; $\mathrm{CH}$ : Switzerland; CPOPC: Council of Palm Oil Producing Countries; CSIA: Chinese Soybean Industry Association; DE: Germany; ETI: Ethical trading initiative; EU: European Union; FAO: Food and Agriculture Organization of the United Nations; GAA: Global Aquaculture Alliance; GAP: Good Aquaculture Practice Thailand; GAPKl: Gabungan Pengusaha Kelapa Sawit Indonesia (Indonesian Palm Oil Association); GB: Great Britain; GLOBALG.A.P.: Global Partnership for Good Agricultural Practice; GSCP: Global Social Compliance Programme; IPOC: Indonesian Palm Oil Commission; IRF: Iceland Responsible Fisheries; ISO: International Organization for Standardization; ISPO: Indonesia Sustainable Palm Oil; MEL: Marine Eco-Label Japan; MPOA: Malaysian Palm Oil Association; MSC: Marine Stewardship Council; MSI: Multi-Stakeholder Initiative; MSPO: Malaysian Sustainable Palm Oil; NGO: Non-Governmental Organization; NL: Netherlands; OECD: Organisation for Economic Cooperation and Development; RFM: Alaskan Responsible Fisheries Management; RSPO: Roundtable for Sustainable Palm Oil; RTRS: Roundtable for Responsible Soy; SIZA: Sustainability Initiative of South Africa; TSC: Transnational Sustainability Certification; US: United States; VietG.A.P.: Vietnamese Good Agricultural Practices; WWF: World Wildlife Fund.
\end{abstract}

\section{Acknowledgements}

Not applicable.

\section{Authors' contributions}

Not applicable. All authors read and approved the finalmanuscript.

\section{Funding}

Open Access funding enabled and organized by Projekt DEAL. This work was supported by the German Ministry for Education and Research under Grant FKZ $031 \mathrm{~B} 0227$

\section{Availability of data and materials \\ Not applicable.}

\section{Ethics approval and consent to participate}

Not applicable.

\section{Consent for publication.}

Not applicable.

\section{Competing interests}

The author declares that he has no competing interests.

Received: 16 June 2020 Accepted: 21 January 2021

Published online: 02 February 2021

\section{References}

1. European Commission (2018) A sustainable bioeconomy for Europe: strengthening the connection between economy, society and the environment: updated bioeconomy strategy. Publications Office of the European Union, Luxembourg

2. European Commission (2012) Innovating for sustainable growth: a bioeconomy for Europe. European Commission, Brussels

3. German Bioeconomy Council (2018) Bioeconomy Policy (Part III)_ Update Report of National Strategies around the World: A report from the German Bioeconomy Council. German Bioeconomy Council, Berlin

4. Levidow L, Birch K, Papaioannou T (2012) EU agri-innovation policy: Two contending visions of the bio-economy. Crit Policy Stud 6(1):40-65. https ://doi.org/10.1080/19460171.2012.659881

5. Birch K, Tyfield D (2013) Theorizing the bioeconomy: biovalue, biocapital, bioeconomics or ... what? Sci Technol Human Values 38(3):299-327. https://doi.org/10.1177/0162243912442398

6. Bugge M, Hansen T, Klitkou A (2016) What Is the Bioeconomy?: A review of the literature. Sustainability 8(7):691. https://doi.org/10.3390/su807 0691

7. Pfau S, Hagens J, Dankbaar B et al (2014) Visions of sustainability in bioeconomy research. Sustainability 6(3):1222-1249. https://doi.org/10.3390/ su6031222
8. Hausknost D, Schriefl E, Lauk C et al (2017) A transition to which bioeconomy?: An exploration of diverging techno-political choices. Sustainability 9(4):669. https://doi.org/10.3390/su9040669

9. D'Amato D, Droste N, Allen B et al (2017) Green, circular, bio economy: a comparative analysis of sustainability avenues. J Clean Prod 168:716-734. https://doi.org/10.1016/j.jclepro.2017.09.053

10. Birch K (2019) Neoliberal bio-economies? The co-construction of markets and natures. Palgrave Macmillan, Cham

11. Meyer R (2017) Bioeconomy strategies: contexts, visions, guiding implementation principles and resulting debates. Sustainability 9(6):1031. https ://doi.org/10.3390/su9061031

12. Backhouse M, Rodríguez F, Tittor A (2019) From a fossil towards a renewable energy regime in the Americas? Socio-ecological inequalities, contradictions and challenges for a global bioeconomy: Bioeconomy \& Inequalities Working Paper No. 10, Jena

13. Böcher $M$, Töller AE, Perbandt D et al (2020) Research trends: bioeconomy politics and governance. For Policy Econ 118:102219. https://doi. org/10.1016/j.forpol.2020.102219

14. Dietz T, Börner J, Förster J et al (2018) Governance of the bioeconomy: a global comparative study of national bioeconomy strategies. Sustainability 10(9):3190. https://doi.org/10.3390/su10093190

15. Ladu L, Imbert E, Quitzow R et al (2020) The role of the policy mix in the transition toward a circular forest bioeconomy. For Policy Econ 110:101937. https://doi.org/10.1016/j.forpol.2019.05.023

16. Moosmann D, Majer S, Ugarte S et al (2020) Strengths and gaps of the EU frameworks for the sustainability assessment of bio-based products and bioenergy. Energ Sustain Soc. https://doi.org/10.1186/s13705-020-00251 $-8$

17. Ladu L, Blind K (2017) Overview of policies, standards and certifications supporting the European bio-based economy. Curr Opin Green Sustain Chem 8:30-35. https://doi.org/10.1016/j.cogsc.2017.09.002

18. Majer S, Wurster S, Moosmann D et al (2018) Gaps and research demand for sustainability certification and standardisation in a sustainable bio-based economy in the EU. Sustainability 10(7):2455. https://doi. org/10.3390/su10072455

19. Vandergeest $P$ (2016) Transnational sustainability certification as a new extraterritoriality? In: Antons C (ed) Routledge handbook on Asian Law. Routledge, London/New York, pp 271-288

20. Ponte S, Daugbjerg C (2015) Biofuel sustainability and the formation of transnational hybrid governance. Environ Polit 24(1):96-114. https://doi. org/10.1080/09644016.2014.954776

21. Vandergeest $P$, Ponte S, Bush S (2015) Assembling sustainable territories: space, subjects, objects, and expertise in seafood certification. Environ Plan A 47(9):1907-1925. https://doi.org/10.1177/0308518X15599297

22. Henriksen LF, Seabrooke L (2016) Transnational organizing: Issue professionals in environmental sustainability networks. Organization (Lond) 23(5):722-741. https://doi.org/10.1177/1350508415609140

23. Vormedal I, Gulbrandsen LH (2020) Business interests in salmon aquaculture certification: competition or collective action? Regul Governance 14(2):328-343. https://doi.org/10.1111/rego.12213

24. Cashore B, Auld G, Newsom D (2004) Governing through markets: forest certification and the emergence of non-state authority. Yale University Press, New Haven

25. Pattberg P (2005) The Institutionalization of Private Governance: how business and nonprofit organizations agree on transnational rules. Governance Int J Policy Admin Inst 18(4):589-610

26. Dingwerth K (2007) The new transnationalism: transnational governance and democratic legitimacy. Palgrave Macmillan, Basingstoke

27. Cashore B (2002) Legitimacy and the privatization of environmental governance: How Non-State Market-Driven (NSMD) Governance Systems Gain Rule-Making Authority. Governance 15(4):503-529

28. Bernstein S (2005) Legitimacy in global environmental governance. J Int Law Int Relat 1(1-2):139-166

29. Bäckstrand K (2006) Multi-stakeholder partnerships for sustainable development: rethinking legitimacy, accountability and effectiveness. Eur Environ 16(5):290-306. https://doi.org/10.1002/eet.425

30. Bernstein S, Cashore B (2007) Can non-state global governance be legitimate? An analytical framework. Regul Governance 1(4):347-371

31. Schleifer P (2013) Orchestrating sustainability: the case of European Union biofuel governance. Regul Governance 7(4):533-546. https://doi. org/10.1111/rego.12037 
32. Ugarte S, Swinkels V (2015) Policy instruments and co-regulation for the sustainability of value chains. ASME Press, New York

33. Steurer $R$ (2013) Disentangling governance: a synoptic view of regulation by government, business and civil society. Policy Sci 46(4):387-410. https ://doi.org/10.1007/s11077-013-9177-y

34. Pattberg P, Stripple J (2008) Beyond the public and private divide: Remapping transnational climate governance in the 21st century. Int Environ Agreements Polit Law Econ 8(4):367-388. https://doi.org/10.1007/s1078 4-008-9085-3

35. Maier J (2016) Zertifizierung für mehr Nachhaltigkeit. In: Friedel R, Spindler EA (eds) Zertifizierung als Erfolgsfaktor: Nachhaltiges Wirtschaften mit Vertrauen und Transparenz. Springer Gabler, Wiesbaden, pp 365-376

36. Geiler N (2018) Label drauf_alles gut? iz3w-informationszentrum 3. welt 368 (September/Oktober 2018): 32-33

37. European Court of Auditors (2016) The EU system for the certification of sustainable biofuels: Special Report No. 18, No 18, 2016. Publications Office, Luxembourg

38. Vogelpohl T, Perbandt D (2019) Biofuel sustainability certifications in the EU: Democratically legitimate and socio-environmentally effective? In: Vogt M (ed) Sustainability certification schemes in the agricultural and natural resource: outcomes for society and the environment. Routledge, London, New York, pp 179-198

39. Moser C, Leipold S (2019) Toward "hardened" accountability? Analyzing the European Union's hybrid transnational governance in timber and biofuel supply chains. Regul Governance 30(4):571. https://doi.org/10.1111/ rego. 12268

40. Stattman S, Gupta A, Partzsch L et al (2018) Toward Sustainable Biofuels in the European Union? Lessons from a decade of hybrid biofuel governance. Sustainability 10(11):4111. https://doi.org/10.3390/su10114111

41. Cheyns E (2011) Multi-stakeholder initiatives for sustainable agriculture: Limits of the 'inclusiveness' paradigm. In: Ponte S, Gibbon P, Vestergaard $J$ (eds) Governing through standards: origins, drivers and limitations. Palgrave Macmillan, London, pp 210-235

42. Elgert $L$ (2012) Certified discourse? The politics of developing soy certification standards. Geoforum 43(2):295-304. https://doi.org/10.1016/j. geoforum.2011.08.008

43. Fortin E, Richardson B (2013) Certification schemes and the governance of land: enforcing standards or enabling scrutiny? Globalizations 10(1):141-159

44. Ruysschaert D, Salles D (2014) Towards global voluntary standards: questioning the effectiveness in attaining conservation goals: the case of the Roundtable on Sustainable Palm Oil (RSPO). Ecol Econ 107(2):438-446. https://doi.org/10.1016/j.ecolecon.2014.09.016

45. Ponte S (2014) 'Roundtabling' sustainability: lessons from the biofuel industry. Geoforum 54:261-271. https://doi.org/10.1016/j.geofo rum.2013.07.008

46. Marin-Burgos V, Clancy JS, Lovett JC (2015) Contesting legitimacy of voluntary sustainability certification schemes: valuation languages and power asymmetries in the roundtable on sustainable palm oil in Colombia. Ecol Econ 117:303-313. https://doi.org/10.1016/j.ecole con.2014.04.011

47. de Man R, German L (2017) Certifying the sustainability of biofuels: promise and reality. Energy Policy 109:871-883. https://doi.org/10.1016/j.enpol 2017.05.047

48. Fortin E (2018) Repoliticising multi-stakeholder standards processes: the Roundtable on Sustainable Biomaterials' standards and certification scheme. J Peasant Stud 45(4):805-824. https://doi.org/10.1080/03066 150.2017 .1285286

49. Glasbergen P (2018) Smallholders do not Eat Certificates. Ecol Econ 147:243-252. https://doi.org/10.1016/j.ecolecon.2018.01.023

50. Pye $\mathrm{O}$ (2019) Commodifying sustainability: development, nature and politics in the palm oil industry. World Dev 121:218-228. https://doi. org/10.1016/j.worlddev.2018.02.014

51. Foley $P$ (2017) The territorialization of transnational sustainability governance: production, power and globalization in Iceland's fisheries. Environ Polit 26(5):915-937. https://doi.org/10.1080/09644016.2017.1343767

52. Sack RD (1986) Human territoriality: its theory and history. Cambridge studies in historical geography. Cambridge Univ. Pr, Cambridge

53. Bassett TJ, Gautier D (2014) Regulation by territorialization: the political ecology of conservation and development territories. EchoGeo. https:// doi.org/10.4000/echogeo.14038
54. Foley P, Havice E (2016) The rise of territorial eco-certifications: new politics of transnational sustainability governance in the fishery sector. Geoforum 69:24-33. https://doi.org/10.1016/j.geoforum.2015.11.015

55. Partzsch L (2020) Alternatives to multilateralism: new forms of social and environmental governance. MIT Press, Cambridge

56. Hajer MA (1995) The politics of environmental discourse. Ecological modernization and the policy process. Oxford University Press, Oxford

57. Hajer MA (2009) Authoritative Governance. Policy-making in the age of mediatization. Oxford University Press, Oxford

58. Hajer MA (2006) Doing discourse analysis: coalitions, practices, meaning In: van den Brink M, Metze T (eds) Words matter in policy and planning. Discourse theory and method in the social sciences. KNAG/Nethur, Utrecht, pp 65-74

59. Ruysschaert D, Carter C, Cheyns E (2019) Territorializing effects of global standards: What is at stake in the case of 'sustainable' palm oil? Geoforum 104:1-12. https://doi.org/10.1016/j.geoforum.2019.05.009

60. Schouten G, Glasbergen P (2011) Creating legitimacy in global private governance: the case of the roundtable on sustainable palm oil. Ecol Econ. https://doi.org/10.1016/j.ecolecon.2011.03.012

61. Schouten G, Bitzer V (2015) The emergence of Southern standards in agricultural value chains: a new trend in sustainability governance? Ecol Econ 120:175-184. https://doi.org/10.1016/j.ecolecon.2015.10.017

62. Schouten $\mathrm{G}$, Hospes $\mathrm{O}$ (2018) Public and private governance in interaction: changing interpretations of sovereignty in the field of sustainable palm oil. Sustainability 10(12):4811. https://doi.org/10.3390/su10124811

63. Meidinger E (2007) Beyond Westphalia: competitive legalization in emerging transnational regulatory systems. In: Brütsch C, Lehmkuhl D (eds) Law and legalization in transnational relations. Routledge, London, pp 121-143

64. Vandergeest $P$, Unno A (2012) A new extraterritoriality? Aquaculture certification, sovereignty, and empire. Polit Geogr 31(6):358-367. https:// doi.org/10.1016/j.polgeo.2012.05.005

65. Hospes $O$ (2014) Marking the success or end of global multi-stakeholder governance? The rise of national sustainability standards in Indonesia and Brazil for palm oil and soy. Agric Hum Values 31(3):425-437. https://doi. org/10.1007/s10460-014-9511-9

66. Swanepoel J (2017) Whose ethics? The international regulation of labour practices on South African export fruit farms. Anthropol Southern Afr 40(4):303-316. https://doi.org/10.1080/23323256.2017.1395709

67. Foley P, Hébert K (2013) Alternative regimes of transnational environmental certification: governance, marketization, and place in Alaska's salmon fisheries. Environ Plan A 45(11):2734-2751. https://doi.org/10.1068/a4520 2

68. Ha TTT, Bush SR (2010) Transformations of Vietnamese shrimp aquaculture policy: empirical evidence from the Mekong Delta. Environ Plann C Gov Policy 28(6):1101-1119. https://doi.org/10.1068/c09194

69. Islam MS (2008) From pond to plate: towards a twin-driven commodity chain in Bangladesh shrimp aquaculture. Food Policy 33(3):209-223. https://doi.org/10.1016/j.foodpol.2007.10.002

70. Hinkes C (2019) Adding (bio)fuel to the fire: discourses on palm oil sustainability in the context of European policy development. Environ Dev Sustain 117(Pt 1):1. https://doi.org/10.1007/s10668-019-00541-y

71. Dauvergne $P(2018)$ The global politics of the business of "sustainable" palm oil. Glob Environ Polit 18(2):34-52. https://doi.org/10.1162/ glep_a_00455

72. Higgins V, Richards C (2019) Framing sustainability: alternative standards schemes for sustainable palm oil and South-South trade. J Rural Stud 65:126-134. https://doi.org/10.1016/j.jrurstud.2018.11.001

73. Soja Plus Goiás (n.d.) Sustainability. https://www.sojaplusgoias.com.br/ en/sustainability/. Accessed 29 May 2020

74. Hugé J, Waas T, Dahdouh-Guebas F et al (2013) A discourse-analytical perspective on sustainability assessment: interpreting sustainable development in practice. Sustain Sci 8(2):187-198. https://doi.org/10.1007/ s1 1625-012-0184-2

75. Down to Earth (2011) Indonesian Sustainable Palm Oil scheme to speed up palm oil development. https://www.downtoearth-indonesia.org/story /indonesian-sustainable-palm-oil-scheme-speed-palm-oil-development. Accessed 29 May 2020

76. Harrison-Dunn A (2015) Cost, cynicism and frustration: Malaysian government launches own palm oil standard. https://www.foodnavigator.com/ 
Article/2015/01/30/Malaysian-government-launches-own-palm-oil-stand ard. Accessed 29 May 2020

77. Wijaya A, Glasbergen P (2016) Toward a new scenario in agricultural sustainability certification?: The response of the Indonesian National Government to private certification. J Environ Dev 25(2):219-246. https:// doi.org/10.1177/1070496516640857

78. efeca (2015) Comparison of the ISPO, MSPO and RSPO Standards, Dorchester/Bournemouth

79. Bastos Lima MG, Gupta J (2014) The extraterritorial dimensions of biofuel policies and the politics of scale: live and let die? Third World Q 35(3):392-410. https://doi.org/10.1080/01436597.2014.893484

80. Pye O (2016) The round table on sustainable palm oil and the palm oil industrial complex. In: Cramb RA, McCarthy JF (eds) The oil palm complex: smallholders, agribusiness and the state in Indonesia and Malaysia. NUS Press, Singapore, pp 409-441

81. Nesadurai HES (2018) New constellations of social power: states and transnational private governance of palm oil sustainability in Southeast Asia. J Contemporary Asia 48(2):204-229. https://doi.org/10.1080/00472 336.2017.1390145

82. Schleifer P (2016) Private governance undermined: India and the roundtable on sustainable palm oil. Glob Environ Polit 16(1):38-58. https://doi. org/10.1162/GLEP_a_00335

83. Schleifer P, Sun Y (2018) Emerging markets and private governance: the political economy of sustainable palm oil in China and India. Rev Int Polit Econ 25(2):190-214. https://doi.org/10.1080/09692290.2017.1418759

84. Thompson L-J, Lockie S (2013) Private standards, grower networks, and power in a food supply system. Agric Hum Values 30(3):379-388. https:// doi.org/10.1007/s10460-012-9404-8

85. Bush SR, Belton B, Hall D et al (2013) Global food supply. Certify sustainable aquaculture? Science 341(6150):1067-1068. https://doi.org/10.1126/ science. 1237314

86. Marschke M, Wilkings A (2014) Is certification a viable option for small producer fish farmers in the global south? Insights from Vietnam. Mar Policy 50:197-206. https://doi.org/10.1016/j.marpol.2014.06.010

87. Solidaridad (2016) Solidifying China and Brazil's strategic soy trade partnership. https://www.solidaridadnetwork.org/news/solidifying-china -and-brazil\%E2\%80\%99s-strategic-soy-trade-partnership. Accessed 29 May 2020

88. Byrne J (2017) EU and Brazilian players act to foster 'more sustainable' soy production and trade: 24.01.2017. https://www.feednavigator.com/Artic le/2017/01/24/EU-and-Brazilian-players-act-to-foster-more-sustainabl e-soy-production-and-trade. Accessed 29 May 2020

89. Sustainability Institute South Africa (2017) Purchasing practices of German discounters and labour conditions on South African wine and grape farms, Lynedoch
90. GLOBALG.A.P. (2017) Number of growers adopting GRASP more than doubled_-SIZA recognized as social audit—INFARM certified as first vertical farming company. https://www.globalgap.org/uk_en/media -events/news/articles/Number-of-Growers-Adopting-GRASP-More-ThanDoubled-SIZA-Recognized-as-Social-Audit-INFARM-Certified-as-First-Verti cal-Farming-Company/. Accessed 29 May 2020

91. SAI Platform/SIZA/WWF (2018) SIZA, the South African sustainability standard for social and environmental assurance, is the first to reach FULL (100\%) equivalence when benchmarked against SAI Platform's Farm Sustainability Assessment (FSA). https://saiplatform.org/our-work/news/ siza-the-south-africansustainability-standard-for-social-and-environmen tal-assurance-is-the-first-to-reach-full-100-equivalence-when-bench marked-against-sai-platforms-farmsustainabilit/. Accessed 25 Jan 2021

92. Reuters (2019) Indonesia certifies a record amount of palm plantations as sustainable. 27 March 2019. Reuters Media. https://www.reuters.com/ article/us-indonesia-ispo/indonesia-certifies-a-record-amount-of-palmplantations-as-sustainable-idUKKCN1R80GJ. Accessed 25 Jan 2021

93. Yusof A (2019) Oil palm growers'licenses will be revoked if not MSPO certified. 19 November 2019. New Straits Times. https://www.nst.com. my/business/2019/11/540067/oil-palm-growers-licenses-will-be-revok ed-if-not-mspo-certified. Accessed 25 Jan 2021

94. Ponte S (2012) The Marine Stewardship Council (MSC) and the making of a market for 'Sustainable Fish.'J Agrarian Change 12(2-3):300-315. https ://doi.org/10.1111/j.1471-0366.2011.00345.x

95. Lang C (2008) Why certification of agrofuels won't work. https://wrm.org. uy/articles-from-the-wrm-bulletin/why-certification-of-agrofuels-wontwork/. Accessed 30 May 2020

96. Greenpeace in Zentral- und Osteuropa (2018) Zeichen-Tricks: Der Gütezeichen-Guide von Greenpeace in Österreich, Wien

97. Kusumaningtyas R (2018) External Concerns on the RSPO and ISPO Certification Schemes, Amsterdam

98. Hidayat NK, Offermans A, Glasbergen P (2018) Sustainable palm oil as a public responsibility? On the governance capacity of Indonesian Standard for Sustainable Palm Oil (ISPO). Agric Hum Values 35(1):223-242. https ://doi.org/10.1007/s10460-017-9816-6

\section{Publisher's Note}

Springer Nature remains neutral with regard to jurisdictional claims in published maps and institutional affiliations.
Ready to submit your research? Choose BMC and benefit from:

- fast, convenient online submission

- thorough peer review by experienced researchers in your field

- rapid publication on acceptance

- support for research data, including large and complex data types

- gold Open Access which fosters wider collaboration and increased citations

- maximum visibility for your research: over $100 \mathrm{M}$ website views per year

At BMC, research is always in progress.

Learn more biomedcentral.com/submissions 